\title{
Role of Media in Empowering Women
}

\author{
Premlata $^{1 *}$ and Tanuja Jukariya ${ }^{2}$ \\ ${ }^{1}$ Department of Extension Education and Communication Management, CHSC, MPUAT, \\ Udaipur (313001), Rajasthan, India \\ ${ }^{2}$ Department of Family Resource Management, CHSC, MPUAT, Udaipur (313001), \\ Rajasthan, India \\ *Corresponding author
}

\section{A B S T R A C T}

\begin{tabular}{|l|}
\hline Ke y w o r d s \\
Role of Media, \\
$\begin{array}{l}\text { Empowering } \\
\text { Women }\end{array}$ \\
\hline Article Info \\
\hline $\begin{array}{l}\text { Accepted: } \\
\text { 12 March } 2018 \\
\text { Available Online: } \\
\text { 10 April } 2018\end{array}$ \\
\hline
\end{tabular}

Media is considered to be the most important tool of society in the modern times as it has the power to reach out to be a large audience by mass communication.The empowerment of women is much needed for the social and economic growth of any society. They are the creators, teachers and developers of any human generation. The social ill treatment and the negligence of economic decision powers to them in such small areas of the countryespecially, directly fall out for this research subject. While on the other hand media being the fourth pillar of our democracy has certain duties to follow in the betterment of society. It can play the role efficiently in transmitting information to society in empowering women by educating the society about their stand and worth.In the present article a number of studies have been reviewed to Increase the participation of women in decision-making through the media and to promote a decent and balanced portrayal of women in the media.

\section{Introduction}

Women empowerment is very essential for the development of the country and it could not be denied that women have capacity to change the destiny of a country. Women are offering their services in two fields, on domestic and economic front. It needs recognition that for the socio-economic development women participation is mandatory and they have ability to mold the nation's fortune (Panigrahy and Bhuyan, 2006). The social and economic empowerment could not be achieved without mass media in the era of technology. Media is often considered as the 4th pillar of the 
society and democratic medium of information. The role of media has become very important in shaping present days society. Media is the part of the life, all around, from the shows one watches on television, music on the radio, the books, magazines and newspapers. It educates people about the current issues and influences the public opinion. The common people rely on media to know about happenings in the society. Media has the power to pressurize and criticize the drawbacks of democracy. It is instrumental in bringing about unity among the masses and is backbone of the nation.

The reach of media to common people has increased and undoubtedly media has attained the role of a very powerful organ in virtually all spheres of life. The electronic media, particularly television, has become the most influential medium of mass communication in India. Television has a myriad of different goals, which range from entertainment to education. Various confines of education and entertainment are depicted in television. It's often looked at as a babysitter for children. The viewing of television can entertain the young and old alike for great amounts of time. It is helping women to empower themselves by using different tools of media. Portrayal of women which is derogatory to their image by media is an evidence of lack of gender sensitivity and has called for making them accountable for such representation of women.

Such instances had led the National Commission for Women to recommend amendment in the Indecent Representation of Women (Prohibition Act) 1986. The government in a move to strengthen the legal machinery protecting the dignity of women, approved amendments to the Indecent Representation of Women (Prohibition) Act, 1986 in 2012.The aim was to include new technologies like MMS and the electronic media and some which were left outside the ambit of the Act like posters and TV serials which perpetuate stereotypes of women. Promoting a balanced and non-stereotyped portrayal of women in the media is very important to use it in a progressive way and avoiding the ill effects of any such medium of Media. Women's knowledge about media and access to and control over the various forms of conventional and modern media is still limited in most societies. The increase in the participation and access of women to selfexpression and decision-making through the media and new technologies of communication is in a way empowering women. The powerful and positive role that the media can play in the empowerment of women and gender equality should be supported and further explored.

Communication is extremely important for women's development and mass media play significant role. It is to be noted that growth of women's education and their entry into employment has contributed to the growth of media. In all spheres of life whether for controlling population growth, spread of literacy or improving quality of life for vast masses, women have crucial role to play. However, women can be expected to play this role when they become conscious of their strength and are not deliberately marginalized by male domination. In this context, media has an important role to play - to create awakening in women to achieve their potential as the prime movers of change in society. In today's world, print and electronic media play a vital role in effectively conveying message that needs to be conveyed

\section{Objectives of the study}

To increase the participation of women in decision-making through the media

To promote a decent and balanced portrayal of women in the media. 


\section{Literature Review}

Moghadam (2007) investigated that media has raised issues of women.

It has highlighted rights of women in the society. It has tried to mold opinion of people regarding rights of women

Ray (2008) stated in his research study that media is very useful tool for the purpose of training and education. He found that media is used for transmitting information to people at large scale, a way of bringing changes in behavior and thinking styles of society.

According to Asif (2013), the development of society can be improved if women are empowered. Role of media is important to empower women because it gives selfreliance and there is a visible effect of media on every sphere of life.

In a blog, The new media and the global women's empowerment movement (2011) by Jammie Victory Abdulai, he said that the new media is the fact that anyone can be part of the global information sharing process by anyone, anywhere in the form of any article and information on social platforms.

Khan and Moin (2013) reported that with access to internet at homes, women are using it for multiple purposes. It has enabled women to participate in important daily affairs of state that ranges from household work to education, health and governance.

A report (2013) on "Women in decisionmaking: The role of the new media for increased political participation" suggested that the new media represents a further digital divide, a number of studies point to the potential positive impact of new media for young women. Primarily, new media provides women with the opportunity to:
Network with other women

Create on line selves which build confidence

Appeal to other women and peers through styles and issues that are directly relevant and attractive

Subhash (2015) concluded in her study "Impact of Mass Media on Women: A Sociological Study of Gulbarga District" that impact of mass media on women has enabled their empowerment, but still there are many suggestions given by women to restrict crime related programmes, improvement of learning and knowledge, equal status of women, gender equality etc. Hence the media should take into the suggestions of women and improve their programmes, telecasts, circulations, knowledge and information.

Narayana and Ahamad (2016) revealed in their study that Media have a great potential for the empowerment of women, however the overall use of this media by women is very low. It also suggested that the powerful and positive role that the media can play in the empowerment of women and gender equality should be supported and further explored. They also found that how media can increase the participation and access of women to expression and decision-making.

Dr. Sonia Gupta (2017) concluded in her study on "A Study on Role of Media in Women Empowerment in India" that that most of the respondents have high empowerment in final say on their health care and decision on employing servants in home 85percent and 90percent respectively, which shows the high percentage rate of the empowered women. Further it was found that in the economic empowerment sphere most of the respondents are empowered nicely. It shows that women in India are empowered and their empowerment percentage indicates a 
medium level of empowerment and high percentage of influence of Media and technology. This is an indication that women are very much aware of the variables which can lead them towards empowerment.

\section{Suggestions and recommendations}

Media have a huge potential for the empowerment of women, however the overall use of this media by women is very low. Media has played an important role in empowering the women.

The way media has played its part in portraying about the atrocities faced by the women and empowering the women, no other sector has done.

Media should create awareness about risks prevailing at home, in work places and while travelling and staying outside home.

Economic self-sufficiency is necessary, though it is not a sufficient condition for empowerment of women.

Public policies are extremely important to strengthen the legal institutions that guarantee equal rights and opportunities to women. The Media should provide political and legal and economic and health awareness.

They should provide knowledge about support groups.

Mass Media should have the positive attitude towards life. Under any adverse circumstance they should not loose courage and confidence and try to end their life.

They should have a strong will power to succeed in life. In short, the inner strength of women has to be built by success stories of other women.
In the era of globalization and with revolution in means of communication and information technology, the media role has become more crucial for women empowerment in India. The Indian media now must focus on women issues in a decisive way as their role is detrimental for the women empowerment in India.

It is essential that media should devote a good percentage of their programmes to create awareness among women and the society at large, give information about women's rights and machineries to approach for their allround development.

They should set goals for their future and strive to achieve them with courage and conviction. Much developmental news should be aired through the medium of radio and tv.

The urban lower middle class women need information mainly on the following topics:

Employment /Job Prospects in India /selflocality.

Inexpensive childcare and Healthcare.

Educational facilities at their doorstep.

Dowry system, other legal rights like selfhelp, violence etc.

Information about NGO's.

Legal provisions against Sexual harassment, Domestic Violence and Social injustice.

The role of Media is very important to accelerate Women empowerment which will lead to social and economic empowerment of women. The Mass Media, however, like all social media, are good and practical means to increase, through the dissemination of healthy concepts of being woman, of what is the role 
of women in modern society, of good examples that women give us every day, of the results they have achieved and continue to reach out to women in many fields of economics and beyond, the social consideration of women, giving to young women good ideas and examples for their economic empowerment. Women, in Indian society, are traditionally expected to confine themselves to domestic environment. Woman's perceived interests linked to domesticity may adversely affect her empowerment outcomes (Aggarwal 1997; Kabeer 1999; Sen 2006). It was found from the women empowerment survey that the women in India are empowered but still her interest towards domesticity affects her empowerment otherwise women would have been more empowered. In fact social power plays an important role in generating/sustaining inequalities between men and women, which plays an important role in generating and sustaining gender inequalities. Also, the hypotheses I have tested have a positive significant relation between dependent variable and independent variables. Only the less percentage of social empowerment and the knowledge of their rights show that the women in India are still not feel secure outside. The freedom of press in the country is a blessing for the people. The government and non-government agencies can work on towards enhancing the women's traits and capabilities. Participation in seminars and lecturers and encouragement for taking waged employment would help or strengthen the role of women in decision making.

Mass Media could also make a strong contribution, with the implementation of media campaigns, to the dissemination of the concept of gender equality. If people see in the media the overcome of the differences between men and women will bring him back into everyday life. The Mass Media have always unconsciously affected and influenced the thinking and behavior of society. Media should focus success stories of established, successful and renowned women in spite of indecent representation of women. As an important agent of socialization shaping of gender roles, its mechanisms for checks and balances with respect to gender need to be strengthened. The media should enable projection of women in a decent and dignified way and promote respect and dignity to women avoiding negative portrayal of women. New innovative decent presentation of women, based on Indian culture and society through media must be introduced. A strong legislative effort coupled with a wide spread social awareness with morality and ethics is needed to fight this menace so that women are not perceived as a commodity but as individual with right and dignity.

\section{References}

Directorate general for internal policies report on "Women in decision-making: The role of the new media for increased political participation" 2013.

Enhancing Women Empowerment through Information and Communication Technology.

Khan, E. A. and Moin, A. (2013). Women Empowerment: Role of New Media. Retrieved from http://www.ocwjournal online.com/Adminpanel/product_image s/7f2535d7e476506d7e2a368e4bdb220c . $\mathrm{p} \mathrm{df}$

Narayana, A. and Ahamad, T. (2016). Role of media in accelerating women empowerment. International Journal of Advanced Education and Research ISSN: 2455-5746. Retrieved from www.newresearchjournal.com/educatio $\mathrm{n}$ Role of mass media in empowerment of women. Retrieved from https://www.slideshare.net/harishhari58 
760608/role-of-mass-media-in-womenempowerment

The responsibility of Women empowerment on media. Retrieved from http://www. legalservicesindia.com/article/article/the -responsibility-of-womenempowerment-on-media- 1657-1.html

Women Empowerment in India www.womenempowermentindia.com Women for sustainable cities http://womenfor sustainablecities.org

\section{How to cite this article:}

Premlata and Tanuja Jukariya. 2018. Role of Media in Empowering Women. Int.J.Curr.Microbiol.App.Sci. 7(04): 1618-1623. doi: https://doi.org/10.20546/ijcmas.2018.704.182 